\title{
A análise política por Max Weber da Revolução de Fevereiro de 1917: um balanço crítico
}

\author{
Luiz Enrique Vieira de Souza' \\ Ricardo Musse
}

\section{Resumo}

O presente trabalho discute criticamente a análise de Max Weber sobre a situação política da Rússia em 1917, particularmente seu artigo sobre a Revolução de Fevereiro [A transição da Rússia à pseudodemocracia]. Nele estabelecemos os nexos entre tal artigo e seus escritos dedicados à revolução russa de 1905, com ênfase para a análise das classes sociais e a viabilidade de uma coalizão democrática capaz de suplantar o czarismo. Em 1917, Weber questiona o caráter democrático do "governo provisório" e conclui que o processo revolucionário se resumiu à anulação de um monarca incompetente, sem alterar a posição conservadora das classes dominantes em relação à questão agrária, nem sua dependência perante os bancos estrangeiros. Assim, analisamos os equívocos que levaram Weber a desconsiderar a possibilidade de uma aliança entre operários e camponeses, bem como as insuficiências de seu esquema teórico para incluir a dinâmica do movimento de massas na transformação histórica.

Palavras-chave: Max Weber. Revolução de Fevereiro. "Pseudodemocracia”. Czarismo.

Em 26 de abril de 1917, pouco mais de um mês após o estopim da Revoluçáo Russa de fevereiro (08 de março no calendário alemáo), Max Weber (2005b) publica na revista Die Hilfe, o artigo "Russlands Übergang zur Scheindemokratie" [A transição da Rússia para a pseudodemocracia]. A opção de divulgar o artigo na revista dirigida por Friedrich Naumann não é casual. Deve-se em parte à interlocução constante entre parceiros Professor do Departamento de Sociologia da Universidade Federal da Bahia Segundo autor: Professor do Depar-
tamento de Sociologia da Universidade de São Paulo.

\section{(c)) EY}

Direito autoral e licença de uso: Este artigo está licenciado sob uma Licença Creative Commons. Com essa licença você pode compartilhar, adaptar, para qualquer fim, desde que atribua a autoria da obra, forneça um link para a licença, e indicar se foram feitas alterações. 
políticos e amigos, intensificada durante a guerra, mas também ao propósito de Weber de influenciar os círculos liberais e burgueses, e mesmo os dirigentes do Reich, alvos preferenciais da revista de Naumann.

A relação entre os dois iniciou-se em 1894. Weber frequentou na ocasiáo, sem uma adesão incisiva, as sessóes da associação comandada por Neumann, a Evangelisch-Sozialer Kongress, então em vias de se transformar em partido político. Apesar de seu ceticismo em relação à viabilidade do projeto, Weber apoiou - inclusive captando fundos financeiros - a malograda candidatura de Neumann ao Reichstag. A dedicação quase integral de Weber à produção científica, não esmoreceu o diálogo entre eles, instaurado nos marcos de uma constante afinidade política² (HEUSS, 1968; WEBER, 1995).

$\mathrm{O}$ artigo publicado na Die Hilfe completa um tríptico iniciado em 1906 com a publicação de dois artigos sobre a Revolução Russa de 1905: Zur Lage der bürgerlichen Demokratie in Russland [A situação da democracia burguesa na Rússia], em fevereiro, e Russlands Übergang zum Scheinkonstitutionalismus [A transição da Rússia a um regime pseudoconstitucional], em agosto, ambos publicados na mais prestigiosa revista acadêmica alemã (Archiv für Sozialwissenschaft und Sozialpolitik). No conjunto da obra de Weber, esse tríptico se insere em duas séries distintas, convergentes em certa medida: os textos de intervenção no debate público alemão - seja este acadêmico, partidário ou político; e a reflexão sobre a dimensão propriamente política dos processos de modernização tardia na Rússia (e na Alemanha).

A publicação da pesquisa empírica realizada por Weber, em 1892, no âmbito da Verein für Sozialpolitik (Associação para a Política Social) sobre a situação dos trabalhadores rurais ao leste do Elba (WEBER, 1993; POLLAK, 1986) suscitou um debate político sobre a questão agrária alemã no qual ele não se furtou em assumir o papel de protagonista. No período que se estende de 1892 a 1899, Weber redigiu grande quantidade de textos e discursos salientando duas linhas interconectadas de desdobramentos dos resultados de sua pesquisa: a discussão da política

2 Friedrich Neumann é o destinatário de parte considerável da correspondência recolhida na seção "Politische Briefe" nas Gesammelte Politische Schriften de Weber (1988b). 
econômica e a determinação dos interesses estratégicos concernentes à soberania do Estado Nacional alemão.

A partir de 1914, com a deflagração da guerra, Weber volta a intervir - com a mesma intensidade da década de 1890 - na discussão sobre os problemas da atualidade, num acompanhamento detido das flutuaçóes da conjuntura histórica e política. Até mesmo o artigo mais denso deste período Parlament und Regierung im neugeordneten Deutschland [Parlamentarismo e governo numa Alemanha reordenada] veio a lume sob a forma de uma sequência de artigos publicados durante o verão de 1917 no jornal Die Frankfurter Zeitung.

Os artigos de intervenção da década de 1890 estão orientados pelas premissas enunciadas por Weber, em 1894, em sua aula inaugural na Universidade de Freiburg, "O Estado nacional e a política econômica". Nesta, além de subordinar a economia à "raison d'état" [Staatsräson] do Estado alemão, descreve como tarefa dos professores de sua geração, considerando suas "responsabilidades diante da história", a interferência ativa na vida política, sem o temor de, no limite, transformar a cátedra em palanque ${ }^{3}$, uma postura que mudaria após o amadurecimento de suas perspectivas metodológicas e conferiria outro tom aos seus escritos políticos a partir da guerra (WEBER, 1986a, 1986b).

Essa diferença torna-se mais clara quando se tem em mente que as determinações de seu esquema conceitual foram estabelecidas, em larga medida no período entre 1903 e 1905, por meio de um acerto de contas com o "historicismo" da escola histórica da economia (a assim chamada "controvérsia metodológica"), com a Geisteswissenschaft na versão formulada por Wilhelm Dilthey, com os princípios da sociologia de Ferdinand Tönnies e Georg Simmel, com a "concepção materialista de história", com o neokantismo logicizante de Windelband e Rickert, com a

3 Comentando a aula inaugural, Michael Pollak (1996, p. 91) diz: "Percebe-se em sua aula inaugural uma estrutura retórica semelhante à de sua conclusão na pesquisa sobre os operários agrícolas, mas o caráter da sequência é outro: depois de uma curta descrição resumindo a enquete, vem a passagem explicativa dos valores que sustentam a análise, ou seja, a razão de Estado que obriga à expansão imperialista. [...] A explicitação da função política da ciência econômica permite a construção de um discurso de pretensão científica, mas que contém, de fato, inúmeros elementos de análise realista, um mínimo de elementos descritivos e um máximo de elementos de ação". 
lebensphilosophie de Friedrich Nietzsche etc. (HEINRICH, 1952; COHN, 2003; RINGER, 2004).

O artigo "A 'objetividade' do conhecimento nas ciências sociais", publicado em 1904, nos Archiv für Sozialwissenschaft und Sozialpolitik, constitui uma espécie de súmula desse novo método de investigação. Weber propóe, como forma de resolução da heterogeneidade entre conceitos e dados empíricos, teoria e história (salientada por Kant e desdobrada no Idealismo alemão), a construção de um "tipo ideal", um "quadro homogêneo de pensamento", uma abstração unilateral que permitiria a formulação de hipóteses a serem comprovadas ou não por uma comparaçẫo histórica sistemática. Por intermédio desse meio de conhecimento, a ciência - apesar de orientar-se pelo significado cultural atribuído - adquire uma "objetividade" que a distingue do subjetivismo inerente aos juízos de valores. O ser e o "dever ser", a ciência e a política constituem-se, assim, como esferas distintas (WEBER, 1986b).

Essa nova perspectiva metodológica modifica não só o método da investigação como também a lógica da exposição. Michael Pollak destaca com precisão essa alteração:

Nos textos anteriores de Max Weber, percebia-se a linha de argumentação típica da retórica política: da descrição passa-se à prescrição e, progressivamente, as conclusões imagináveis vão sendo reduzidas à única conclusão desejável do ponto de vista do autor. Porém, nos textos científicos de Weber escritos mais tarde, ele se preocupa com a clareza descritiva e analítica, não formula conclusões em termos de ação, e - à guisa de conclusão - inúmeros textos de Weber terminam em termos prospectivos, que destacam não uma única solução, mas diversos desdobramentos possíveis"(POLLAK, 1996, p. 95).

Em linhas gerais, o artigo publicado na revista Die Hilfe segue esse modelo. $\mathrm{O}$ texto organiza-se sob a forma de uma descriçáo analítica da situaçáo de momento (abril de 1917) na Rússia. O próprio Weber salienta, nas primeiras linhas, que busca um "julgamento sóbrio" e evitaria fazer "profecias sobre o futuro andamento da revoluçáo" (WEBER, 1984b, p. 238). Nas páginas finais, no entanto, quando se coloca a questão das relaçôes da Alemanha com o governo então no poder na Rússia, ele retorna à fórmula da década de 1890 , a da prescrição que solicita uma ação inequívoca.

Embora o artigo "A transição da Rússia para a pseudodemocracia" (WEBER, 2005b) se apresente como uma peça única, sem subdivisōes, é 
possível discernir partes em que se concentra a discussão de tópicos determinados. No primeiro bloco investiga-se a conexão causal responsável pela Revolução de Fevereiro, tendo em vista a situação de estabilidade política e social vigente após os eventos de 1905-19064. Destaca o sufocamento da insurreição popular de 1905-1906, reforçado pela emergência de um Estado de "caráter policial" (WEBER, 1984b, p. 246); a criação de uma ideológica unidade nacional predominante nos círculos da intelligentsia (tanto da rural e como da urbana), tributária do tratamento concedido à demanda por autonomia das nacionalidades no interior da Rússia e, sobretudo, do exercício de uma política externa expansionista e imperialista. $\mathrm{O}$ ponto principal, no entanto, consistiria nas reformas promovidas sob o comando de Piotr Stolypin (Ministro do Interior), em especial a reforma agrária que realizou "[...] a hábil manobra de fracionar em duas partes desiguais, inevitável e profundamente antagônicas, um dos grupos sociais revolucionários nucleares, os camponeses da antiga Rússia” (WEBER, 1984b, p. 188).

Uma das partes oriundas desse fracionamento seria composta pelos camponeses que se tornaram proprietários privados superando a condição - na qual a maioria ainda se encontrava - de proletários do "comunismo de aldeia”. Weber completa o quadro descrevendo o grupo que denomina de "terceiro elemento"s, o círculo da intelligentsia que mantinha contato permanente com o campesinato. Posicionados geralmente em oposição interna à administração estatal de caráter policialesco tornaram-se os principais "portadores da propaganda social-revolucionária no campo" (WEBER, 1984b, p. 188).

4 Os protestos agrários que levaram os mujiques literalmente a incendiar propriedades no campo em 1906-1907 foram respondidos por Piotr Stolypin com tal violência que ele ficaria conhecido na história russa como o "enforcador". Já no período entre 191। e 1913, a Rússia voltou a experimentar uma forte inquietação entre o operariado fabril, expressa numa nova onda de greves (LUXEMBURGO, 20I7, p. 24). À luz desses fatos, deve-se relativizar a afirmação de Weber segundo a qual o interstício entre 1905 e 1917 teria representado um período de estabilidade política e social na Rússia.

5 Na descrição de Weber, "[...] dele faziam parte os numerosos empregados de salário fixo mal remunerado das grandes ligas (uniões) autoadministrativas dos zemstvos. Entre eles achava-se a quase totalidade da intelligentsia ativa na administração. Igualmente, todo o pessoal do trabalho agronômico e de veterinária, tão importantes na Rússia, e quase todo o trabalho que entre nós chamamos de 'economia popular' além do ensino na escola primária leiga e dos médicos rurais empregados com salário fixo" (WEBER, 1984b, p. 239). 
No mundo urbano, no período entre 1905 e 1917, Weber ressalta que "multiplicou-se fortemente o proletariado industrial" (WEBER, 1984b, p. 240), cada vez mais desvinculado da aldeia de origem, com concentraçóes de trabalhadores nas entáo "poucas empresas gigantescas da indústria pesada”. À luz desta alteração na estrutura social, os protestos de 23 a 28 de fevereiro obrigaram Nicolau II a abdicar do trono, abrindo caminho para a formação de um "governo provisório" composto de representantes das principais classes e orientaçóes políticas da sociedade russa. Suplantou-se assim o principal obstáculo ao êxito de processos revolucionários, descritos por Weber na chave de uma constatação: “a experiência feita há pouco em toda parte" comprova que, atualmente, "[...] revoluçốes que tenham sucesso mais do que efêmero não podem ser realizadas nem pela burguesia e intelligentsia burguesa sozinhas nem pela massa proletária e inteligência proletária somente" (WEBER, 1984b, p. 240).

A indagação acerca das motivações da Revolução de Fevereiro concentra-se assim na elucidação dos fatores que conduziram a essa improvável aliança, ainda que momentânea, entre burguesia, proletariado e campesinato. $\mathrm{O}$ alvo imediato da investigação torna-se, por conseguinte, o modo de proceder do czar, as açóes políticas que estimularam a união de todos contra ele. Weber não poupa Nicolau II da responsabilidade pelo desenlace da insurreição. Acusa-o de "por vaidade" recair no "engano pernicioso de ele próprio querer governar” (WEBER, 1984b, p. 243) - motivação oculta da demissão de Serguei Witte - mesmo sem dispor do cabedal necessário para essa função ${ }^{6}$.

A perquirição, entretanto, não se detém aí. Indaga porque, antes da revolução, não se conseguiu "[...] anular um soberano politicamente incapaz de [gerir] seus próprios interesses e os da nação” (WEBER, 1984b, p. 244). Para Weber, isso somente seria possível num regime parlamentarista, pois o corpo de funcionários especializado responsável pela administração do Estado, por mais eficiente que seja, não se encontra imbuído do poder efetivo

6 Para justificar o juízo que qualifica o czar como um mero "diletante", Weber enumera requisitos que considera imprescindíveis na atividade política e na arte de governar: "rigorosa objetividade, segura visão, reservado autocontrole, capacidade de ação silenciosa” (WEBER, I984b, p. 244). 
A análise política por Max Weber da Revolução de Fevereiro de 1917: um balanço crítico | Luiz Enrique Vieira de Souza, Ricardo Musse

e da responsabilidade necessária para o cumprimento dessa tarefa ${ }^{7}$. Diz ele: “[...] o poder parlamentar condena, [...] mediante uma seleção de simples eficácia, o soberano politicamente incapaz, e só ele, à impotência - e isto é de longe sua realização mais importante" (WEBER, 1984b, p. 245-246).

A investigação desdobra-se, assim, num questionamento tão recorrente nos escritos políticos de Weber que talvez não seja demasiado considerá-la como uma hipótese derivada de uma construção de "tipo ideal" a ser elucidada por intermédio da comparação histórica: como e por que sociedades com processos de modernização retardatária, nas quais o desenvolvimento capitalista é tardio, suscitam obstáculos quase intransponíveis à consolidação dos princípios do liberalismo constitucional e à implantação do regime político parlamentarista?

No tríptico composto pelos artigos sobre as Revoluçóes Russas de 1905 e 1917, mas também no artigo Parlament und Regierung im neugeordneten Deutschland, Weber procura situar essa investigação num espectro amplo. Elimina-se, dessa forma, de saída qualquer possibilidade de encontrar como resposta uma determinação unívoca, um fundamento último - seja ele de natureza econômica, política ou cultural. Nos dois casos, porém, a exposição demora-se na análise da configuração das classes e grupos sociais relevantes.

O tríptico inicia-se com o artigo, publicado em fevereiro de 1906, "A situação da democracia burguesa na Rússia”" Nele, Weber (2005a) coloca

7 A contraposição entre poder político e gestão administrativa é retomada e desenvolvida no artigo Parlament und Regierung im neugeordneten Deutschland. Nele, conforme a síntese de Gabriel Cohn (2016, p. I43): “[...] o parlamento é valorizado por algo mais do que seu papel de órgão da representação política mediante os partidos. Trata-se do terreno no qual podem brotar novas lideranças políticas. E o governo é concebido como centro do exercício do poder propriamente político mais do que da coordenação das medidas administrativas correntes".

8 No período que se seguiu ao "domingo sangrento" e à irrupção das greves de massas nos centros urbanos durante a Revolução de 1905-1906, Weber dedicou-se com afinco à aprendizagem do idioma russo. Em poucas semanas, já era capaz de formular suas análises com base na leitura de diferentes fontes da imprensa russa e dos principais programas em disputa no império czarista. Além disso, valeu-se de uma frutífera interlocução com cientistas e estudantes russos que participavam do círculo de leituras fundado em Heidelberg pelo médico N. I. Pirigov, onde a revolução de 1905 havia provocado vividas discussões sobre as propostas constitucionais do movimento democrático russo (DAHLMANN; MOMMSEN, 1989). A densidade dessas reflexões expressou-se, em 1906, na publicação de dois artigos no Archiv für Sozialwissenschaft und Sozialpolitik, que perfazem dois extensos volumes com centenas de notas de rodapé (inéditas em português), nos quais 
a pergunta sobre a existência de classes sociais em condições de serem "portadoras" dos valores da liberdade e da autonomia individual na disputa contra a autocracia. Sua reflexão detém-se sobre a possibilidade de se engendrar uma coalizáo de interesses capaz de derrotar o czarismo e alçar princípios liberais ao plano constitucional.

Naquele momento, Weber expressou sua simpatia pela causa da intelligentsia burguesa, reunida no Partido Constitucional-Democrata (kadets), e dos elementos atuantes nos zemstvos, conselhos comunais criados por Alexandre II após a derrota na Guerra da Crimeia. Ainda que de maneira cética, Weber enxergava no império a leste uma série de pré-condições favoráveis ao surgimento de uma cultura livre. A Rússia dispunha de um vasto território que potencializava suas chances de desenvolvimento econômico, além de contar com as vantagens de ainda não ter atingido o estágio de racionalização burocrática que impunha entraves à livre iniciativa, nem aquele grau de saturação cultural que uniformizava os estilos de vida no Ocidente. Esses fatores eram importantes aos olhos de Weber porque uma eventual derrota do czarismo poderia alterar a correlação de forças em prol do liberalismo em toda a Europa e, ao mesmo tempo, oferecer bases mais favoráveis para as relaçóes diplomáticas entre Rússia e Alemanha (SOUZA, 2017, p. 9-19).

O desenrolar dos conflitos levou Weber, porém, à conclusão de que as possibilidades de vitória do liberalismo eram diminutas porque os ideais da intelligentsia burguesa não encontravam apoio em camadas mais amplas da sociedade russa. Os conflitos de interesses entre os empresários industriais e a classe trabalhadora inviabilizaram uma coalizáo dos setores urbanos contra o czarismo, ao passo que os membros da nobreza agrária - mesmo aqueles inicialmente ativos no âmbito dos zemstvos - perfilaram ao lado da autocracia em resposta à "fome de terras" do campesinato.

\footnotetext{
Weber mobilizou não apenas os fatos relacionados à conjuntura política, mas também conhecimentos sobre a literatura russa do século XIX e as tradições da Igreja Ortodoxa (WEBER, 197 Ia, p. 234-353, I97 Ib). Embora naquela ocasião também se referisse despretensiosamente aos seus artigos como "notas ao estilo de crônicas", Weber desenvolveu ali formulações de caráter sociológico coerentes com seus pressupostos metodológicos do "pluralismo causal", esmiuçando em alguma medida os interesses materiais e ideais das camadas sociais e partidos envolvidos nos conflitos (SOUZA, 20I7; MATTA, 2006).
} 
Nesse cenário, Weber não conseguiu vislumbrar de onde poderia surgir o impulso para implantar as propostas dos programas do campo democrático. Apesar de ter encarado a luta emancipatória na Rússia "com profunda participação e comoção interior” (WEBER, 2005a, p. 118), suas observaçóes não lhe permitiram estabelecer afinidades substanciais entre o liberalismo constitucional e as condiçóes econômicas do "alto capitalismo" [Hochkapitalismus], matriz do processo de modernização na Rússia (e, em larga medida, também na Alemanha).

No segundo artigo do tríptico, publicado em agosto de 1906, "A transição da Rússia a um regime pseudoconstitucional”, Weber interpreta os zig-zags políticos do czarismo à luz de sua dependência dos bancos estrangeiros. Com o intuito de aplacar as críticas da opinião pública internacional - mas, sobretudo, para apaziguar os credores de Berlim e Paris em relação aos seus investimentos na Rússia -, o governo publicou o "Manifesto de Outubro", uma declaração redigida pelo ministro Sergei Witte que estabelecia direitos civis assentados no princípio da inviolabilidade da pessoa e assegurava as liberdades de "consciência", "expressão", "reunião" e "organização", além de promover a Duma de órgão consultivo a órgão legislativo (WEBER, 1971b, p. 165-401).

De maneira emblemática, porém, o manifesto foi pregado nos muros das cidades russas ao lado da ordem dada poucos dias antes pelo General Trepov ao Exército para "não poupar munição" na coibição de motins. Ao fim e ao cabo, as perseguiçóes continuaram; então, Weber demonstrou que cada uma das garantias oferecidas no documento não tinha mais valor que uma letra morta. A autocracia limitou as atribuiçóes da Duma, esvaziando-a de poderes e tratando com animosidade a representaçáo popular. O caráter "pseudoconstitucional" do novo regime tornou-se explícito quando a oposição venceu por duas vezes as eleiçóes e a resposta do czar em ambas as ocasióes foi a dissolução do parlamento. Contudo, depois que novos empréstimos foram obtidos, nem a Duma nem Witte se faziam mais necessários; pelo contrário, a essa altura a estabilidade do regime e também os ânimos dos credores estrangeiros passaram a depender, sobretudo, da capacidade repressiva da autocracia. 
Weber considerou, no entanto, que o "Manifesto de Outubro" iria produzir um efeito duradouro: a perda relativa dos poderes do czar diante do aparato burocrático. As novas disposiçóes consolidariam no terreno institucional o predomínio do aparato administrativo, promovendo uma centralização do poder capaz de reordenar a situação caótica da realidade política anterior (WEBER, 1971b). Weber incorreu, porém, no equívoco de levar demasiado a sério as novas diretrizes legais. Tal como antes, o aparato administrativo russo continuou a pouco diferir do retrato feito por Nikolai Gógol (2009) na peça O Inspetor Geral. As alteraçóes institucionais não se mostraram efetivas no sentido de limitar os caprichos do czar, nem permearam a administração pública com parâmetros de racionalidade que coibissem várias de suas práticas arbitrárias costumeiras.

O terceiro artigo, publicado em abril de 1917, “A transição da Rússia para a pseudodemocracia” (WEBER, 2005b), retoma tópicos, análises e conceitos presentes nos dois artigos de 1906. O termo Scheindemokratie, por exemplo, utilizado para caracterizar a natureza do processo em curso em 1917, remete a Scheinkonstitutionalismus, adjetivo com o qual Weber designa o regime político implantado em 1906. A repetição do qualificativo "Schein" indica, portanto, sua discordância da tese de que a Revolução de Fevereiro acarretaria mudanças substantivas na política russa.

Segundo Weber, a burguesia havia apoiado a sublevação popular apenas para se desembaraçar de um monarca incompetente que havia levado o país ao caos. O "governo provisório" é descrito como um carro sem direção, no qual o peso maior cabia aos representantes conservadores da burguesia industrial, aos militares de carreira, ao quadro burocrático e aos credores das finanças nacional e estrangeira. Assim, Weber minimiza a participação no governo de representantes da intelligentsia revolucionária, considerando-os como pouco mais que instrumentos das antigas elites para manter a sua autoridade política.

Weber reconhecia a força de mencheviques e socialistas-revolucionários (herdeiros da tradição narodnik, cujo principal expoente em 1917 era Alexander Kerensky) que dispunham naquele momento dos meios de comunicação e transportes, além de contarem com apoios de parcela dos 
quadros da burocracia rural. No entanto, apesar disso, sustentou que a presença de radicais no governo se devia apenas à estratégia das velhas elites conservadoras de manter a aparência revolucionária do novo regime, sem enfraquecer o controle que exerciam sobre o aparelho de Estado.

No segundo bloco, a exposição se desenrola em torno da determinação do caráter do processo em curso. Weber avaliou, na contracorrente do debate alemão sobre a situação vigente na Rússia (BROUÉ, 2005), que a sequência de acontecimentos decorrentes da insurreição de fevereiro, em especial a formação de um "governo provisório", não configurava propriamente uma "revolução", como, aliás, a expressão do título "pseudodemocracia” já indicava. Ele resume, em uma frase e em tom categórico, o resultado de sua análise quanto a esse ponto: "Até agora se realizou não uma revolução, mas um simples desligamento de um monarca "incapaz" (WEBER, 1984b, p. 253).

Essa conclusão assenta-se em consideraçóes de duas ordens, o exame das relaçóes de poder, no âmbito do "governo provisório", entre os representantes políticos da burguesia, do proletariado e do campesinato; e uma consideração demorada das possibilidades de coalizão entre classes com demandas bastante diferentes. Os acelerados desdobramentos da insurreição - intensificados num cenário de derrotas parciais na guerra e de persistente desabastecimento - forçaram os círculos burgueses e a elite política a aceitar a supressão da linha dinástica (na prática, a derrubada da monarquia) e a compor um governo com indesejados representantes dos camponeses e do proletariado.

Weber pondera que o "governo provisório" configura uma situação de equilíbrio altamente instável que irá desembocar em um dos dois desdobramentos possíveis: a ditadura militar ou a democracia. Cabe observar que Weber sequer menciona, nem mesmo como possibilidade longínqua, a opção que veio a prevalecer em outubro, a "revolução social" ou "proletária”, apesar de este termo ser recorrente na propaganda dos círculos radicais. Na sua ótica, se a tendência predominante no momento fosse invertida e o processo em andamento desaguasse numa "revolução", o que se teria, no limite, seria uma mudança de regime político. 
O diagnóstico de Weber, decorrente de uma análise do poder desigualmente distribuído no interior do "governo provisório", prevê que é "[...] muito pouco provável que um desenvolvimento para uma ditadura militar clara ou velada não se realize, caso a guerra continue" (WEBER, 1984b, p. 248). Ele justifica essa previsão por meio de uma análise dos interesses prevalecentes entre as forças majoritárias no governo. Segundo Weber, três setores decisivos temem a democracia e, por conseguinte, esforçam-se para manter a continuidade da guerra: os oficiais de carreira (logo, o comando das Forças Armadas); as camadas burguesas na Duma e no "governo provisório"; e as finanças internas e externas (corporificadas nas bolsas e no setor bancário).

Assim como em seus escritos da década anterior, Weber sublinhou que as pressóes dos credores estrangeiros continuavam a definir os contornos da política russa. As demais potências da Entente, França e Inglaterra, financiavam não só os gastos militares, mas também o combate da burguesia russa aos seus "inimigos internos". Em outras palavras, a permanência da Rússia na guerra era tanto uma contrapartida aos empréstimos concedidos pelos aliados como uma maneira de imobilizar no front a massa de camponeses que demandava a redistribuiçáo das terras.

Essa tática concedia às elites uma margem de tempo para reorganizar o aparato repressivo necessário para conter os elementos radicais nos centros urbanos e nos vilarejos. Nas palavras de Weber (1984b, p. 249): "Os senhores Miliukov e Gutschkov dirigem seu olhar para os bancos internos e externos, e agora para a América - não com a finalidade primeira de levar adiante a guerra, mas para se firmarem na sela contra os radicais". Weber desacreditava da possibilidade de que a ala efetivamente democrática do "governo provisório" revertesse a hegemonia da coalizão entre grande burguesia, latifundiários e antigos funcionários, pois Kerenski e seus aliados não dispunham de Kreditfähigkeit perante os bancos estrangeiros nem das condiçóes para assumir as responsabilidades pela administração pública sem o apoio destes setores.

Ao focar sua análise na coalizão de interesses entre bancos estrangeiros e as camadas proprietárias em prejuízo do campesinato, Weber concluía que a política russa permanecia como antes de 1917. Mesmo que os cam- 
poneses representassem a imensa maioria do povo russo e efetivamente desejassem o fim da guerra, suas reivindicações materiais não poderiam ser satisfeitas sem uma ampla reforma que desapropriasse as terras da nobreza agrária e daquela pequena parcela de camponeses ricos (kulaks) que havia sido favorecida pelas medidas adotadas por Piotr Stolypin em 1907 para modernizar a produção agrícola e conter os distúrbios agrários que se seguiram à primeira revolução.

As resistências das camadas proprietárias às exigências dos camponeses eram tanto maiores porque o desequilíbrio nas finanças do Estado inviabilizava o pagamento de indenizações pelas desapropriações. Além disso, a dívida externa também jogava um papel importante na questão agrária. Nas palavras de Weber (1984b, 249):

[...] recai sobre os camponeses a cobertura dos juros da dívida externa, repete-se o processo descrito pela economia política russa: essa camada subnutrida é obrigada por meio de violentos impostos a ceder para a exportação o cereal exigido para cobrir aqueles juros.

A incompatibilidade entre os interesses da burguesia e as demandas dos camponeses explicaria as açóes dos representantes políticos da camada dirigente para procrastinar a realização das já convocadas eleiçóes para a Assembleia Constituinte. O êxito dessas articulaçóes decorria, na avaliaçáo de Weber, da hesitação dos representantes do campo democrático no governo em romper com a situação de dependência da Rússia em relação às finanças internacionais.

Assim, de certo modo, na medida em que subordina o desenrolar dos acontecimentos políticos ao poder e ao controle dos bancos estrangeiros, Weber projeta o futuro como uma reiteração das experiências do passado. O "julgamento sóbrio", a preocupação em permanecer atento ao jogo da Realpolitik descartando arroubos e utopias românticas, mostra aqui os seus limites. Mesmo que a pressão desses credores tenha sido decisiva para as manobras do "pseudoconstitucionalismo" durante a revoluçáo de 1905, Weber não percebeu que a iminência da derrota militar e o colapso do aparato estatal criavam agora uma situação de descontentamento entre as massas que os "empréstimos da liberdade" já não seriam capazes de mitigar (COLLINS, 2001, p. 188). 
Em suas considerações acerca das possibilidades de coalizão entre as três classes principais, burguesia, proletariado e camponeses, o tratamento que Weber concede a cada uma delas vai além de uma mera descrição estática da estratificação social. As análises de cada caso procuram ressaltar a dinâmica que se estabelece por meio de um complexo jogo de conexóes entre relaçôes de afinidade ou solidariedade e os interesses contraditórios que estão na base de conflitos permanentes. Nesta análise de um caso concreto, a situação das classes no âmbito da Revolução de Fevereiro, o critério decisivo é a posição da burguesia, do proletariado e do campesinato diante da possibilidade de configuração de uma coalizão duradoura que sustentasse um regime democrático não efêmero.

O diagnóstico de Weber de que o advento de uma ditadura militar clara ou velada era a hipótese mais provável não era de forma nenhuma descabido. Tanto assim que essa perspectiva esteve no horizonte no final de agosto de 1917, quando o então comandante do Exército, general Lavr Kornilov, enviou tropas para Petrogrado. No entanto, o fato de Weber sequer ter vislumbrado como hipótese, ainda que improvável, os rumos que o processo revolucionário russo tomaria em outubro (o que náo deixa de ser espantoso tendo em vista sua acuidade como analista político), é algo que demanda explicação. Esta talvez se encontre na enumeração de seus equívocos de avaliação acerca das afinidades e contradiçôes que possibilitavam ou impediam alianças de classe.

Aos seus olhos, seria inconcebível a formação de um governo num Estado moderno sem a participação da burguesia, pois mesmo um empresário com pouco ou nenhum dinheiro na carteira gozaria de mais confiança que quaisquer elementos das camadas populares, especialmente quando estes se orientassem por ideais coletivistas (OZHIGANOV, 2019, p. 128). Além disso, Weber não levou suficientemente em consideração as especificidades históricas locais ao desacreditar a viabilidade de uma coalizão entre operários e camponeses na Rússia. Mesmo tendo em diversas ocasióes questionado o materialismo vulgar da Segunda Internacional, Weber adotou como referência Gueorgui Plekhânov (expoente teórico menchevique e representante do evolucionismo econômico) para afirmar um suposto antagonismo de interesses entre proletários e mujiques. 
Segundo o esquema de Plekhânov, os operários enxergariam os camponeses como uma massa atrasada pautada pelo "ideal pequeno burguês de igualdade e divisão", cujos anseios poderiam deter o desenvolvimento industrial russo por muitos anos (GETZER, 1984). Os ganhos materiais dos operários na indústria da guerra lhes seria vantajoso, assim como o interesse na redução do preço do pão - fatores contrários ao anseio camponês pela paz e pela valorização na cotação dos cereais. "Os líderes socialistas dos trabalhadores podem, pela obstrução da administraçáo, obter concessóes políticas de um governo burguês - não, porém, de uma Constituinte de camponeses" (WEBER, 1984b, p. 253). Weber, portanto, não apenas descartou o prognóstico de uma aliança operário-campesina, como também sublinhou que os trabalhadores urbanos partilhavam do interesse das elites de manter o campesinato nas trincheiras.

Para além de quaisquer elementos conjunturais, é importante ponderar em que medida a leitura de Weber sobre as alianças de classe era tributária de uma incorporação parcial dos próprios escritos de Marx sobre o tema. Afinal de contas, tanto no Manifesto do Partido Comunista e em O 18 Brumário de Luis Bonaparte, o fundador do materialismo histórico se expressa em termos bastante críticos em relação ao campesinato, pontuando seus vínculos com o antigo regime, seu apego à propriedade privada $\mathrm{e}$ seu caráter amorfo em termos de consciência de classe.

No entanto, como se tratavam de reflexóes expostas em correspondências privadas que se mantiveram relativamente pouco conhecidas mesmo entre expoentes da socialdemocracia, Weber desconhecia o fato de que, no final de sua vida, Marx inclinou-se a rever com base nas especificidades russas os argumentos que havia aplicado ao campesinato da Europa Ocidental. Marx também se dedicou ao estudo da língua russa para analisar mais detidamente as tradiçóes da obshchina (mir), uma instituição que garantia a propriedade coletiva das terras e sua periódica redistribuição entre os camponeses.

Com base nesse fundamento de propriedade coletiva, Marx reconheceu que os mujiques poderiam assumir uma posiçáo anticzarista e, em aliança com o proletariado nascente de Sáo Petersburgo e Moscou, lançar as bases para uma sociedade superior do ponto de vista civilizatório, sem 
necessariamente atravessar o estágio intermediário do desenvolvimento capitalista. Marx foi explícito ao dizer que essa hipótese lutava contra o tempo, uma vez que as forças de mercado já estavam sendo patrocinadas pelo Estado e corroíam paulatinamente os fundamentos da obshchina. Além disso, postulou que dependeria também das açóes do proletariado ocidental, sem as quais as potências da Europa provavelmente enviariam suas tropas em socorro ao czar (MARX, 2013, p. 71-116).

A ênfase desmedida nas manobras dos círculos dirigentes não permitiu, entretanto, que Weber atentasse para a dinâmica das mobilizações que alteraram decisivamente a correlação de forças na Rússia e expulsou os Romanov do poder. Não lhe pareceu muito relevante que o estopim para a derrubada do czar tenha se consumado a partir do enfrentamento liderado pelas operárias das fábricas têxteis de São Petersburgo, que foram capazes náo apenas de angariar a solidariedade dos trabalhadores de outras indústrias, mas inclusive estabelecer diálogo com os soldados destinados à repressão e convencê-los a abaixar suas armas, descumprindo as ordens superiores para pôr fim às agitaçóes. Essa investida representava o ápice de um movimento grevista que envolveu cerca de 590.000 operários entre setembro de 1916 e fevereiro de 1917, no qual 80\% das paralizaçóes incluíam exigências políticas (CHRETIEN, 2017). Numa palavra, tratava-se de um processo que revelava o desgaste da população civil com as repercussóes negativas da guerra no plano interno e o acirramento de uma disputa em que o anseio pela paz era cada vez mais associada à necessidade de democratização das instituiçóes políticas.

Já em relação às agitações no meio agrário, a queda da monarquia catalisou a iniciativa dos camponeses, que desenvolveram uma multiplicidade de estratégias para forçar a desapropriação de terras.

Alguns camponeses se engajaram em revoltas clandestinas simplesmente abrindo os portões e permitindo que o gado de todo o vilarejo se alimentasse no pasto dos donos das terras. Algumas comunidades produziram documentos aparentemente oficiais que lhes garantiram o uso dos recursos locais perpetuamente. Revoltas mais ousadas viram os camponeses trabaIhando juntos para derrubar a madeira das florestas da vizinhança (BADCOCK, 20I7, p. 2).

Os mujiques formavam a principal base de recrutamento para o exército e também já se sentiam exauridos pelo esforço de guerra, particularmente 
porque o ônus dos empréstimos internacionais representava para eles uma sobrecarga fiscal que lhes arrancava boa parte do fruto de seus trabalhos. Nesse contexto, a ação coletiva dos camponeses mostrou-se a tal ponto efetiva que o "Decreto sobre a Terra", editado pelos bolcheviques após a Revolução de Outubro, pode ser interpretado como a legitimação de uma conquista que os mujiques alcançaram por si mesmos, pois a essa altura eles já haviam expropriado vastas extensões de latifúndio.

A recapitulação dos fatos históricos nos remete, portanto, ao debate sobre os limites das teses sociológicas de Weber sobre poder e dominação. Isso porque suas formulaçóes sobre a concentração dos meios administrativos e do monopólio da violência legítima colocam no centro da discussão política a relação entre um núcleo circunscrito de dirigentes e os funcionários especializados que implementam segundo procedimentos racionais os objetivos formulados por aquelas lideranças que se encontram à frente do Estado. É claro que esse argumento não se restringe às instituiçóes estatais, valendo também para a relação entre dirigentes partidários e as "máquinas" burocráticas que sustentam as disputas encabeçadas por suas agremiaçóes (WEBER, 1968, p. 55-70). De qualquer forma, esse esquema teórico-conceitual sobre a racionalização da esfera política confere uma atenção insuficiente para a ação coletiva das massas e seu papel na transformação histórica. As massas são representadas não como protagonistas dos conflitos por seus próprios interesses materiais e ideais, mas como séquito [Gefolgenschaft] em disputa pelas elites políticas.

$\mathrm{Na}$ realidade, esses pressupostos conformam o substrato da teoria política weberiana que, em termos sociológicos, encontra sua formulação mais sistemática nas passagens de Economia \& Sociedade dedicadas aos "tipos de dominação" (capítulo III) e à "sociologia da dominação" (capítulo IX). Em que pese as importantes diferenças traçadas por Weber entre ciência e política - isto é, entre a esfera dos juízos de fato e a esfera dos juízos de valor - a "teoria dos pequenos círculos" figura como um elemento comum tanto aos seus escritos sociológicos como àqueles dedicados à intervenção nos debates políticos de seu tempo.

No plano teórico analítico, Weber considera a ação coletiva imediata das massas nos Estados modernos inviável porque nessas condiçóes o 
processo decisório não responderia aos critérios de agilidade e eficácia garantidos pela centralização do poder (WEBER, 2004, p. 716-752). Além disso, as massas representariam disrupçốes emotivas que interfeririam na estabilidade das instituiçóes e na racionalidade da açáo política, de forma que exercício do poder direto pela população ou mediado por conselhos seriam incompatíveis com as exigências da Realpolitik. "As 'massas' [...], independentemente de quais camadas sociais as componham em cada circunstância, pensam somente até depois de amanhã” (WEBER, 1988a, p. 404). Já no plano normativo, Weber esquivou-se de considerar em maiores detalhes aqueles desenhos institucionais que ampliariam a participação política das massas para além da eleição de partidos ou lideranças carismáticas, porque as estruturas de poder popular originadas no bojo de revoluçóes - como os sovietes na Rússia, ou os conselhos de operários e soldados, na Alemanha - haviam se constituído na esfera de influência dos socialistas, ameaçando as possibilidades de coalizão das classes urbanas sob a hegemonia burguesa (SELL, 2019).

No caso da política russa, a "teoria dos pequenos círculos" resultou num enquadramento que impediu Weber de reconhecer a eficácia da ação política das massas e as originalidades institucionais que dela resultaram. $\mathrm{Na}$ realidade, o surgimento dos conselhos de operários (sovietes) como polos de enfrentamento ao czarismo remonta à revolução de 1905, e não deixa de ser emblemático que Weber tenha solenemente ignorado sua relevância ao longo da jornada de lutas que marcaram o choque do operariado contra a autocracia naquele período (MATTA, 2006, p. 205).

Com a Revolução de Fevereiro, já não era possível silenciar a respeito da existência dos sovietes - que agora também abarcava uma importante parcela das forças armadas ao lado dos trabalhadores urbanos -, pois a Rússia vivenciava uma situaçáo de "duplo poder", na qual os decretos do Governo Provisório somente eram executados se não contradissessem as diretrizes formuladas pelos sovietes. Mesmo assim, a "teoria dos pequenos círculos" acarretou importantes distorçôes analíticas porque levou Weber a considerar a situação da democracia na Rússia e os prognósticos da paz quase que exclusivamente se remetendo aos membros do Governo Provisório, particularmente à ala militarista encabeçada por Miliukov. 
"A grande politica é sempre feita por pequenos círculos de pessoas. Decisivo para o sucesso, no entanto, é: 1) que suas decisôes não sejam perturbadas pelas ideias de um monarca tão inepto politicamente como o czar; 2) que tenham atrás de si a dedicação livre de uma camada social suficientemente ampla e forte; 3) que saibam como as lutas pelo poder são conduzidas ali onde regulamento, comando, obediência militar ou burocrática segundo a natureza das coisas não sejam os meios técnicos de sua implementação - e este é o caso da grande política” (WEBER, 1984b, p. 245). Essa passagem revela que Weber considerava praticamente inexorável a participação da Rússia até o fim da guerra porque subestimava a capacidade de pressão das massas em suas exigências pela paz imediata e por concessões democráticas. Por essas razóes, nosso argumento crítico em relação à "teoria dos pequenos círculos" demonstra afinidades com a avaliação de Maurício Tragtenberg (2005, p. 42-43), quando este afirma em relação a Weber que

[...] seu sistema político não reconhece nas massas nenhuma espécie efetiva de capacidade de ação: com efeito, para Weber qualquer atividade política pressupõe a existência intramuros de pequenos grupos manobrando em concordância com a alta burocracia e os meios que controlam as finanças e o crédito. Persuadido desta verdade, Weber articula os dados factuais de que dispõe. Vê na Revolução de Fevereiro uma vulgar escroquerie, um golpe montado pela pequena burguesia acumpliciada com a finança internacional, ocidental; quanto ao golpe de Estado de outubro, trata-se de outra escroquerie, imputável desta vez ao Exército.

De qualquer forma, é importante salientar que nossas considerações críticas ao papel subalterno conferido por Weber à intervenção das massas na história não implicam o equívoco oposto de propor uma teoria cega que ignore a "Razão de Estado" e os critérios de eficácia na administração das sociedades modernas. Nossos argumentos tampouco recaem na visão ingênua de afirmar que os princípios de organizaçáo política e o papel dos círculos dirigentes sejam irrelevantes nos momentos em que as massas deixam os bastidores para assumir o protagonismo da "grande política". Pelo contrário, a efervescência das massas forja o surgimento de novas lideranças e reorganiza o tabuleiro das forças políticas preexistentes (LUXEMBURGO, 2017). Além disso, tal percepção não implica uma visão das massas como sujeito necessariamente homogêneo, sem divisóes políticas internas, como atestariam as cisóes no movimento de massas na Alemanha 
contemporânea à revolução russa. Por fim, reconhecer o protagonismo das massas não significa atribuir juízos de valor necessariamente positivos ao conteúdo de suas intervençôes em cada momento específico ou num determinado período histórico. Nesse sentido, um olhar sociológico mais acurado demandaria uma leitura mais dinâmica sobre as relaçóes entre massas e círculos dirigentes, na qual as massas não fossem retratadas sempre e univocamente como portadoras de uma lógica imediatista a ser manipulada nas disputas entre pequenos círculos de organizaçóes concorrentes.

Embora Weber não tenha publicado uma análise detalhada da Revolução de Outubro, os principais contornos de sua interpretação acerca da tomada do poder pelos bolcheviques foram delineados em sua conferência sobre o "Socialismo", que realizou no verão de 1918 para um grupo de oficiais na Universidade de Viena, e em algumas passagens de outra conferência, "A Política como Vocação", dessa vez ministrada aos estudantes da Universidade de Munique, justamente no momento a experiência dos Conselhos de Operários e Soldados disputavam os rumos da reordenação institucional na Alemanha. Segundo Weber, essa revolução teria sido um fenômeno excepcional, decorrente do colapso político e militar do Estado russo, agravado pelo desespero das massas famintas, que elevara ao poder uma ditadura militar de sargentos liderada por intelectuais diletantes (WEBER, 1984c, p. 629). Em outras palavras, a revolução não deveria ser creditada às massas operárias animadas de "consciência de classe", mas à aliança de interesses entre a intelligentsia radical e um proletariado de soldados que buscavam recompensas materiais.

Dessa forma, Weber minimizou uma vez mais o protagonismo dos operários e camponeses, subtraindo de sua análise a consideração por quaisquer "interesses ideais" que os tenham levado a aderir ao programa bolchevique. Seu julgamento náo levou em consideraçáo o fato de que a maioria dos elementos ativos nos sovietes apenas migrou da esfera de influência menchevique para o bolchevismo a partir da revolta contrarrevolucionária da burguesia e dos latifundiários sob a liderança do general czarista Kornilov. Assim, a mesma intelligentsia burguesa que, em fevereiro, se valeu da oposiçáo das massas ao czarismo para assumir o poder, conspiraria seis meses depois com o Batalhão da Terceira Cavalaria para dispersar os sovietes e, a 
partir disso, fortalecer o "governo provisório". Os bolcheviques foram os principais articuladores da resistência ao assalto das tropas de Kornilov a Petrogrado; somente a partir de então, foram vistos por setores crescentes da população como os únicos efetivamente comprometidos com a defesa da República e as negociaçóes por uma paz imediata. Em resumo, os episódios de fevereiro e agosto demonstram que os principais responsáveis pela derrocada do czar foram as massas de operários e soldados de Petersburgo e Moscou, e não o exército imperialista alemáo ou a intelligentsia burguesa na Rússia (LUXEMBURGO, 2017, p. 24).

A tomada do poder pelos bolcheviques se deu num contexto de acirramento da luta de classes na Alemanha, fortalecendo os grupos da esquerda radical. Weber considerou essa influência deletéria, mas duvidou que Lenin e seus correligionários seriam capazes de se manter por muito tempo à frente do Estado. "O bolchevismo é uma ditadura militar como qualquer outra, e irá entrar em colapso como qualquer outra. A sociedade burguesa não poderá ser transformada em uma utopia socialista por uma revolução. A consequência de uma revolução seria a invasão pelo inimigo e, mais tarde, um regime reacionário" (WEBER, 1995, p. 572). Do ponto de vista político, Weber apontava como fragilidade do bolchevismo uma suposta incapacidade para dirigir a máquina do Estado em tempos de paz. Esse argumento corroborava-se no esforço da intelligentsia revolucionária para cooptar os elementos do antigo quadro de funcionários e assim garantir a manutenção da administração pública e da economia. Ao seu ver, essa colaboração somente era possível em virtude da coerção imposta pelo exército vermelho, mas dificilmente perduraria quando a guerra civil encontrasse seu fim (WEBER, 1984c, p. 629).

O paradoxo histórico condensado na revolução bolchevique consiste; porém, no fato de que as condiçóes "tão diabolicamente difíceis" nas quais se realizou a tomada do poder justificaram, perante Lenin e seus correligionários, uma relação instrumental com as massas populares e a democracia $^{9}$ (LUXEMBURGO, 2017, p. 105). Enquanto no período anterior à

9 Na realidade, as afinidades do pensamento de Lenin com a "teoria dos pequenos círculos" já haviam se anunciado desde sua defesa do "centralismo democrático" na polêmica com os mencheviques em 1902 (LENIN, 1986). 
revolução o fortalecimento dos sovietes oferecia um canal para a expressão das massas no espaço público, no período subsequente à tomada do poder as liberdades democráticas foram suprimidas uma a uma: Assembleia Constituinte, sufrágio universal, liberdade de imprensa e reunião. Os bolcheviques esperavam que a revolução dos trabalhadores alemães pudesse criar as bases para a construção de um ambiente mais permeável à democracia na Rússia, mas, quando viram frustradas essas esperanças, até mesmo a palavra de ordem "todo poder aos sovietes" foi progressivamente esvaziada em favor da centralização do poder no Conselho do Comissariado do Povo, dirigido por Lenin de maneira quase monocrática (WEBER, 2004, p. 223).

Já do ponto de vista propriamente econômico, Weber contrapôs as teses do socialismo evolucionário - referenciando-se uma vez mais em Plekhánov - ao empreendimento de uma revolução socialista na periferia do capitalismo. Nesse sentido, uma revolução socialista seria particularmente inviável naqueles contextos em que o capitalismo não estivesse plenamente "maduro", de modo que somente uma "seita" ignoraria a questão da “[...] evolução por etapas, que até hoje é o dogma do verdadeiro marxismo, [...] e acreditaria que a Rússia poderia saltar os estágios de desenvolvimento da Europa Ocidental” (WEBER, 1984c, p. 623). Com relação a esse argumento, já demonstramos anteriormente que aquilo que Weber nomeia de "dogma do verdadeiro marxismo" não corresponde aos nexos dialéticos que Marx enxergava entre as revoluçóes na Rússia e no Ocidente.

De qualquer forma, Weber reconheceu que a centralização do poder favorecia a modernização econômica da Rússia, uma vez que o uso da força permitia que iniciativas de socialização viessem acompanhadas de medidas características do sistema de produção capitalista dos países economicamente avançados.

[...] Os soviéticos conservaram, ou melhor, restabeleceram a figura do empreendedor amplamente remunerado, o trabalho forçado, o sistema Taylor, a disciplina no exército e na fábrica e chegam a lançar olhares para os capitais estrangeiros. Numa palavra, para colocarem em marcha a máquina econômica e estatal, viram-se eles condenados a adotar tudo quanto condenaram como instituições da classe burguesa, além disso, reintegram nas velhas funções os agentes da antiga Ochrana (polícia secreta czarista), transformando-os em instrumentos essenciais do poder político. (WEBER, 1968, p. 85). 
Por essas razões, Weber julgava que as perspectivas de emancipação política e econômica do proletariado russo não se realizariam sob o regime bolchevique. Mais do que isso, Weber assumia como um dado inexorável que o socialismo sempre implicaria restriçóes ainda maiores para as liberdades individuais, pois o amálgama do capital com o Estado eliminaria a concorrência entre as burocracias pública e privada e, desse modo, estrangularia qualquer possibilidade de livre iniciativa. Os trabalhadores tampouco alcançariam pelo socialismo a superação da "alienação do trabalho", pois nesse cenário escapariam à autoridade do capitalista para recair sob o jugo de uma "ditadura de funcionários" (WEBER, 1984c, p. 621). Em virtude de seus valores pessoais expressos nas metas da afirmação da Alemanha como Machtstaat, de suas análises sobre o primado da "eficácia" na condução do Estado moderno e da inexorabilidade da luta pelo poder entre "pequenos círculos", Weber descartaria também os argumentos daqueles socialistas alemães que refutavam o bolchevismo em nome de uma democracia socialista, na qual os conselhos poderiam atuar como uma espécie de Nebenparlament que alargasse as bases para a educação política das massas e sua expressão criativa, sem que isso implicasse excessos autoritários. "A escolha hoje não é entre democracia e ditadura. A questáo colocada pela história na agenda é: democracia burguesa ou democracia socialista” (LUXEMBURG apud BROUÉ, 2005, p. 166).

\section{Referências}

BADCOCK, Sarah. As revoluçôes camponesas de 1917. Disponível em: https://blogdaboitempo. com.br/2017/09/12/a-revolucao-dos-camponeses-de-1917-especial-revolucao-russa/. Acesso em: 12 maio 2020.

BROUÉ, Pierre. The German Revolution 1917-1923. Boston: Brill, 2005.

CHRETIEN, Todd. Eyewitnesses to the Russian Revolution. Chicago: Haymarkt Books, 2017.

COHN, Gabriel. Crítica e resignaçáo. Max Weber e a teoria social. São Paulo: Martins Fontes, 2003.

COHN, Gabriel. Soberania e responsabilidade - Weber sobre parlamento e governo. In: COHN, Gabriel. Weber, Frankfurt: teoria e pensamento social. Rio de Janeiro: Azougue, 2016. p. 143-157.

COLLINS, Randall. Weber and the Sociology of Revolution. Journal of Classical Sociology, v. 1, n. 2, 171-94, 2001.

DAHLMANN, Dittmar; MOMMSEN, Wolfgang J. Einleitung. In: WEBER, Max. Max Weber Gesamtausgabe. Vol. 10. Tübingen: Mohr Siebeck, 1989. 
GETZER, Israel. Gueorqi V. Plekhânov: a danação da ortodoxia. In: HOBSBAWM, Eric. J. História do marxismo. Vol. 3. São Paulo: Paz e Terra, 1984. p. ?

GÓGOL, Nikolai. O Inspetor Geral. In: GÓGOL, Nikolai. Teatro Completo. São Paulo: Editora 34, 2009.

HEINRICH, Dieter. Die Einheitet der Wissenschaftlehre Max Webers. Tübingen: J. C. B.: Mohr, 1952.

HEUSS, Theodor. Friedrich Naumann - Der Mann, das Werk, die Zeit. Hamburg: Siebenstern Taschenbuch Verlag, 1968.

LUXeMbURGO, Rosa. A Revoluçáo Russa. São Paulo: Fundação Rosa Luxemburgo, 2017.

MARX, Karl. O 18 Brumário. São Paulo: Paz e Terra, 1997.

MARX, Karl. Manifesto do Partido Comunista. São Paulo: Penguin Classics; Companhia das Letras, 2012.

MARX, Karl. A correspondência entre Vera Ivanova Zasulitch e Kar Marx. In: MARX, Karl; ENGELS, Friedrich. Lutas de Classes na Rússia. São Paulo: Boitempo, 2013.

MATTA, Sérgio da. Max Weber e o destino do "despotismo oriental". Revista Brasileira de Ciências Sociais, São Paulo, v. 21, n. 61, p. 203-207, 2006.

MOMMSEN, Wolfgang J. Max Weber and German Politics (1890/1920). Chicago; London: The University of Chicago Press, 1984.

OZHIGANOV, Edward. Weber's and Sorokin's Analytical Treatment of the Russian Revolutions. Russian Sociological Review, v. 18, n. 2, p. 120-137, 2019.

POLLAK, Michael. Un Texte dans son Contexte. L'enquête de Max Weber sur les ouvriers agricoles. Actes de la Recherche en Sciences Sociales, v. 65, p. 69-75, 1986.

POLLAK, Michael. Max Weber: elementos para uma biografia sociointelectual (parte II). Mana, v. 2, n. 2, p. 85-113, 1996.

RINGER, Fritz. A metodologia de Max Weber. São Paulo: Edusp, 2004.

SELL, Carlos Eduardo. Carnaval Revolucionário: Max Weber e a Revolução de Novembro (19181919) na Alemanha. Revista Brasileira de Ciência Política, Brasília, n. 30, p. 159-98, 2019.

SOUZA, Luiz Enrique Vieira de. Espelho Convexo: os escritos de Max Weber, Rosa Luxemburg, Karl Kautsky e Eduard Bernstein sobre a revolução russa de 1905. São Paulo: Editora Alameda, 2017.

TRAGTENBERG, Maurício. Max Weber e a revolução russa. In: WEBER, Max. Estudos Políticos: Rússia 1905 e 1917. Rio de Janeiro: Azougue Editorial, 2005.

WEBER, Marianne. Biografía de Max Weber. México D. F.: Fondo de Cultura Econômica, 1995. 
WEBER, Max. A Política como Vocação. In: WEBER, Max. Ciência e Política - duas vocaçôes. São Paulo: Cultrix, 1968.

WEBER, Max. Zur Lage der bürgerlichen Demokratie in Russland. Archiv für Sozialwissenschaft und Sozialpolitik. Vol. 22. London: Johnson Reprint Corporation, 1971a.

WEBER, Max. Russlands Übergang zum Scheinkonstitutionalismus. Archiv für Sozialwissenschaft und Sozialpolitik. Vol. 22. London: Johnson Reprint Corporation, 1971b.

WEBER, Max. Gesammelte Aufsätze zur Wissenschaftlehre.Tübingen: Mohr Siebeck, 1973.

WEBER, Max. Die Lage der Landerbeiter im ostelbischen Deutschland. In: WEBER, Max. Max Weber Gesamtausgabe. Tubingen: Mohr Siebeck. 1984a.

WEBER, Max. Russlands Übergang zur Scheindemokratie. In: WEBER, Max. Zur Politik im Weltkrieg. Schriften und Reden 1914. Max Weber Gesamtausgabe. Tübingen: Mohr, 1984b.

WEBER, Max. Der Sozialismus. In: In: WEBER, Max. Zur Politik im Weltkrieg. Schriften und Reden 1914. Max Weber Gesamtausgabe. Tübingen: Mohr, 1984c.

WEBER, Max. O Estado Nacional e a Política Econômica. In: COHN, Gabriel (org.). Weber. São Paulo: Ática, 1986a. p. 58-78.

WEBER, Max. A “objetividade” do conhecimento nas ciências sociais. In: COHN, Gabriel (org.). Weber. São Paulo: Ática, 1986b. p. 79-127.

WEBER, Max. Parlament und Regierung im neugeordneten Deutschland. In: WEBER, Max. Gesammelte politische Schriften. Tübingen: Mohr Siebeck, 1988a.

WEBER, Max. Gesammelte politische Schriften. Tübingen: Mohr, 1988b.

WEBER, Max. Landarbeiterfrage, Nationalstatt und Volkswirtschaftspolitik. In: WEBER, Max. Max Weber Gesamtausgabe. Tubingen: Mohr Siebeck, 1993.

WEBER, Max. Economia y Sociedad. México D. F.: Fondo de Cultura Econômica, 2004.

WEBER, Max. A situação da democracia burguesa na Rússia. In: WEBER, Max. Estudos Políticos/ Rússia 1905 e 1917. Rio de Janeiro: Azougue Editorial, 2005a.

WEBER, Max. A transiçẫo da Rússia à pseudodemocracia. In: WEBER, Max. Estudos Políticos/ Rússia 1905 e 1917. Rio de Janeiro: Azougue Editorial, 2005b. 


\section{Max Weber's political Analysis of the February Revolution of 1917: a crtical Review}

\section{Abstract}

This paper critically discusses Max Weber's analysis of the political situation in Russia in 1917, particularly his article on the February Revolution [Russia's transition to pseudo-democracy]. We establish the links between this article and his writings on the Russian revolution of I905, focusing on the analysis of social classes and the viability of a democratic coalition capable of supplanting tsarism. In 1917, Weber questions the democratic character of the "provisional government" and concludes that the revolutionary process was nothing but the annulment of an incompetent monarch, without changing the conservative position of the ruling classes in relation to the agrarian question, nor their dependence on foreign banks. Thus, we analyze the mistakes that led Weber to disregard the possibility of an alliance between workers and peasants, as well as the insufficiencies of his theoretical scheme to include the dynamics of the mass movement in the historical transformation.

Keywords: Max Weber. February Revolution. "Pseudodemocracy. Tzarism. 